\title{
Research on the High Strength Glass Ceramics/Mullite Ceramics Composites
}

\author{
Yijun Liu ${ }^{1,2}$, Jianfeng Huang ${ }^{*}$, Xiufeng Wang ${ }^{1}$, Qiang Yang ${ }^{1}$, Yaqin Wang ${ }^{1}$, Peiwen Rao ${ }^{2}$, \\ Qinggang Wang ${ }^{2}$
}

\author{
${ }^{1}$ Key laboratory of Auxiliary Chemistry and Technology for Chemical Industry, Ministry of Education, Shanxi University of Science \\ and Technology, Xi’an, China; ${ }^{2}$ Guangdong Monalisa Industry Co. ltd, Foshan, China. \\ Email: hjfnpu@163.com
}

Received April 2 ${ }^{\text {nd }}, 2011$; revised April 30 ${ }^{\text {th }}, 2011$; accepted May $7^{\text {th }}, 2011$.

\begin{abstract}
In order to improve the bending strength of mullite ceramic thin tiles, $\mathrm{SiO}_{2}-\mathrm{ZnO}-\mathrm{Na} a_{2} \mathrm{O}-\mathrm{Y}_{2} \mathrm{O}_{3}$ glass was prepared on the surface of the tiles. The influences of the thermal properties and thermal expansion coefficient of the glass and the sintering temperature on the structure and the property of the composites were investigated by differential thermal analysis (DTA), X-Ray Diffraction (XRD), Raman and scanning electron microscopy (SEM). The bending strength of the composites was measured with an universal testing machine. Results show that the crystallization temperature of the $\mathrm{SiO}_{2}-\mathrm{ZnO}-\mathrm{Na}_{2} \mathrm{O}-\mathrm{Y}_{2} \mathrm{O}_{3}$ glass is higher than that of $\mathrm{SiO}_{2}-\mathrm{ZnO}-\mathrm{Na}_{2} \mathrm{O}$ glass. The corresponding crystallites show more complex structure for the $\mathrm{SiO}_{2}-\mathrm{ZnO}-\mathrm{Na}_{2} \mathrm{O}-\mathrm{Y}_{2} \mathrm{O}_{3}$ glass. The thermal expansion coefficients of both glasses are lower than the mullite ceramic tiles. The bending strength of the composites after sintering at $1150^{\circ} \mathrm{C}$ was obviously improved by $10.7 \%$ to $106.2 \mathrm{MPa}$, compared with the mullite ceramic tiles.
\end{abstract}

Keywords: Glass Ceramics, Mullite Ceramics Thin Tile, Composites, Bending Strength

\section{Introduction}

Large ultra-thin dry-pressing thin ceramic tiles have many excellent properties, such as thinness, large size (900 mm $\times 1800 \mathrm{~mm} \times 5.5 \mathrm{~mm}$ ), lower weight (only $1 / 3$ - 1/2 of regular ceramic wall and floor tile) and saving of source material and energy and reducing of dust and gas. It is becoming one of developing low-carbon green environmental new product advocated by all the countries in the world [1]. However, the large ceramic thin tiles still have many problems during the course of processing and application due to their large size and thinness, especially the poor mechanical strength of the product $[2,3]$. In order to solve this problem, thin mullite ceramic tiles are developed to increase their strength greatly [4]. To improve the strength of the mullite ceramics thin tile further and get a good decoration effect, a kind of microcrystal glass is prepared on the surface of the mullite ceramics and a better result is achieved. Recently, the theory analysis and practical application of microcrystal glass composited to ceramic board has made rapid progress [5]. Usually, ceramic tile is used as a matrix and about $5-10 \mathrm{~mm}$ microcrystal glass frit is added on its surface. Then, it is sintered at high temperature and finally the glass/ceramic composites are obtained. It is widely used as a decorating material on vestibule, post, internal and external walls of stations, hotels, halls and entertainment facilities [6].

In the present work, the following method to combine microcrystal glass with ceramic board is used. On the surface of the large-size ultra-thin mullite ceramic tile $(900 \mathrm{~mm} \times 1800 \mathrm{~mm} \times 5.5 \mathrm{~mm})$, ceramic glass of $1 \mathrm{~mm}$ thickness is prepared. The strength of the ceramic tile is greatly raised according to optimizing processing. The influences of the thermal properties and thermal expansion coefficient of the glasses and the sintering temperature of the composites on the structure and the property of the composites were investigated.

\section{Experimental}

Details for the preparation of the mullite ceramic tile $(900 \mathrm{~mm} \times 1800 \mathrm{~mm} \times 5.5 \mathrm{~mm})$ were reported in [4]. The raw materials were as follows: $50 \mathrm{wt} \%$ - $55 \mathrm{wt} \%$ fly ash, $30 \mathrm{wt} \%$ - $35 \mathrm{wt} \%$ pyrophyllite, $10 \mathrm{wt} \%-15 \mathrm{wt} \%$ bauxite and $4 \mathrm{wt} \% \mathrm{AlF}_{3}$.

Microcrystal glass was a sort of borosilicate glass and 
the composition is shown in Table $\mathbf{1 .}$

High purity silica, reagent grade boric acid, zinc oxide, sodium carbonate and yttrium oxide were used as source materials and mixed in the above ratios, ball milled and dried. Then, the mixture was ground in a platinum crucible and kept it at $1500^{\circ} \mathrm{C}$ for $3 \mathrm{~h}$. The molten glass transformed from the mixture at high temperature and underwent water quenching and a course of drying and ball milling to produce a glass power with an average size about 1 - $3 \mu \mathrm{m}$. These glass powder was distributed uniformly by distributor on the surface of mullite ceramic tile and its thickness was kept at $1.2 \mathrm{~mm}$. Next, the covered tile was placed in a furnace for a second sintering at $1000^{\circ} \mathrm{C}-1200^{\circ} \mathrm{C}$, causing the glass powder to remelt, nucleate, crystallize and combinesolidly with the ceramic base. After cooling down to the room temperature, the large-size ultra-thin mullite glass ceramic tile was prepared finally.

\section{Characterization}

Subsequently, the phase composition of the sample was characterized by a Rigaku D/max-3C X-ray diffractometer (XRD) and Raman spectroscopy. The thermal stability and morphologies of the sample were analyzed by a NETZSCH STA 409 PC/PG (DTA) and JSM-6390A (JEOL) scanning electronic microscope (SEM) respectively. The characterization of the mechanical property of the sample was measured by a universal material testing machine (Taiwan Baoda Co. Ltd) and the testing of the bulk density of the sintered sample was carried out by the underwater weighing method and then the porosity of the sample was calculated.

\section{Results and Discussion}

\subsection{The Sintering Behaviors of the Ceramic Glass Mullite Board}

Most research about microcrystal ceramic board show that the range of the mullite crystallization temperature of the ceramic thin tile is about $900^{\circ} \mathrm{C}-1200^{\circ} \mathrm{C}$ with the content of mullite crystal increasing as the temperature rise. The property of the sample is mainly dependent upon the range of crystallization of ceramic glass and the effective controlling. If the ceramic tile base and the glass produce many more crystals, the mechanical property of the composite tile would be greatly improved.

Table 1. The composition of $\mathrm{SiO}_{2}-\mathrm{ZnO}-\mathrm{Na}_{2} \mathrm{O}-\mathrm{Y}_{2} \mathrm{O}_{3}$ glasses/ mol\%.

\begin{tabular}{cccccc}
\hline No. & $\mathrm{SiO}_{2}$ & $\mathrm{~B}_{2} \mathrm{O}_{3}$ & $\mathrm{ZnO}$ & $\mathrm{Na}_{2} \mathrm{O}$ & $\mathrm{Y}_{2} \mathrm{O}_{3}$ \\
\hline 1 & 37 & 18 & 20 & 25 & - \\
2 & 37 & 18 & 20 & 20 & 5 \\
\hline
\end{tabular}

Figure 1 shows the DTA curves of the as-prepared glasses. The endothermic peak observed at nearly $740^{\circ} \mathrm{C}$ is when $\mathrm{Y}_{2} \mathrm{O}_{3}$ was added into the glass, which might be caused by the rebuliding of the structure in the course of melting the glass. The exothermic peak at $880^{\circ} \mathrm{C}$ might have been caused by the crystallization of the glass phase. The crystallization of glass can decrease the content of the glass phase which is not helpful to the densification of the composites, so increasing the crystallizaion tempe- rature of the glass can improve the sintering of the composites. It is proved that the addition of $\mathrm{Y}_{2} \mathrm{O}_{3}$ can increase the crystallization temperature of glass to $950^{\circ} \mathrm{C}$ nearly the crystallization temperature of mullite ceramic, which is very beneficial to the optimization of its structure.

The porosity of the as-prepared glass/ceramic composites sintered at different temperatures was showed in Figure 2. The addition of different glass on the surface

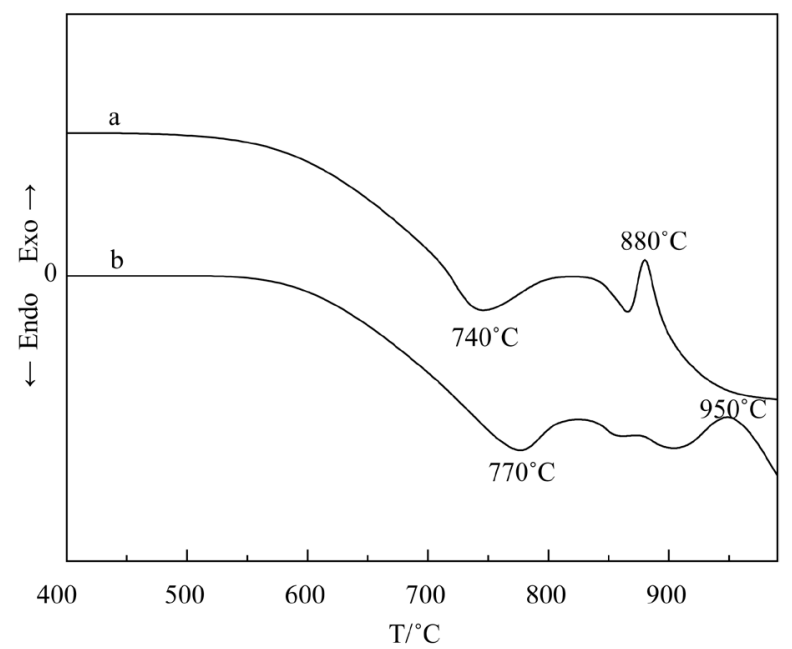

Figure 1. DTA curves of the as-prepared glasses (a. $\mathrm{SiO}_{2^{-}}$ $\mathrm{ZnO}-\mathrm{Na}_{2} \mathrm{O}$; b. $\mathrm{SiO}_{2}-\mathrm{ZnO}-\mathrm{Na}_{2} \mathrm{O}-\mathrm{Y}_{2} \mathrm{O}_{3}$ ).

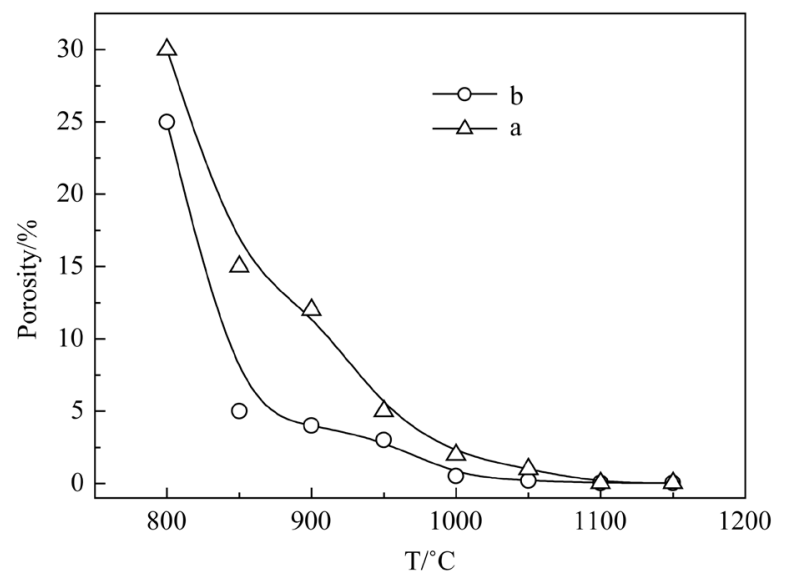

Figure 2. Porosity of the as-prepared glasses/ceramics composites sintered at different temperatures (a. $\mathrm{SiO}_{2}-\mathrm{ZnO}$ $\mathrm{Na}_{2} \mathrm{O}$; b. $\mathrm{SiO}_{2}-\mathrm{ZnO}-\mathrm{Na}_{2} \mathrm{O}-\mathrm{Y}_{2} \mathrm{O}_{3}$ ). 
of ceramic board had a great impact on the property of the composites. When the $\mathrm{SiO}_{2}-\mathrm{ZnO}-\mathrm{Na}_{2} \mathrm{O}-\mathrm{Y}_{2} \mathrm{O}_{3}$ glass was added on the surface of ceramic board, the density of the composites reached its highest at $1050^{\circ} \mathrm{C}$ with a corresponding porosity of less than $0.3 \%$. Comparatively, when the $\mathrm{SiO}_{2}-\mathrm{ZnO}-\mathrm{Na}_{2} \mathrm{O}$ glass was used as the glass coating, a temperature of $1100^{\circ} \mathrm{C}$ was required to make the composites so dense. The higher crystallization temperature of the $\mathrm{SiO}_{2}-\mathrm{ZnO}-\mathrm{Na}_{2} \mathrm{O}-\mathrm{Y}_{2} \mathrm{O}_{3}$ glass relative to the $\mathrm{SiO}_{2}-\mathrm{ZnO}-\mathrm{Na}_{2} \mathrm{O}$ glass might be the reason for this.

\subsection{The Structure and Property of the Glass/Ceramic Composites Board}

Figure 3 shows the surface XRD patterns of the as-prepared glasses. A weak bun peak can be observed on the surface of the glass after sintering, which proves that the crystal of the surface was either amorphous or the crystal is was too small to generate the peak.

There were $\mathrm{ZnB}_{4} \mathrm{O}_{7}$ and $\mathrm{ZnSiO}_{4}$ peaks in the $\mathrm{SiO}_{2}{ }^{-}$ $\mathrm{ZnO}-\mathrm{Na}_{2} \mathrm{O}-\mathrm{Y}_{2} \mathrm{O}_{3}$ glass, which indicate the existence of the crystal. In order to confirm the structure of the crystal, the sample was analyzed by Raman spectroscopy. The crystallization of $\mathrm{B}_{2} \mathrm{O}_{3}$ and $\mathrm{SiO}_{2}$ was found in the $\mathrm{SiO}_{2}-\mathrm{ZnO}-\mathrm{Na}_{2} \mathrm{O}$ glass through the testing (Figure 4), though the intensity of those peaks decreases with the increasing of the temperature. Additionally, the Raman testing of the $\mathrm{SiO}_{2}-\mathrm{ZnO}-\mathrm{Na}_{2} \mathrm{O}-\mathrm{Y}_{2} \mathrm{O}_{3}$ glass showed that the presence $\mathrm{Y}_{2} \mathrm{O}_{3}$ crystals and the silicate melting structure of $\left[\mathrm{Si}_{2} \mathrm{O}_{7}\right]$ and $\left[\mathrm{SiO}_{4}\right]$ (Figure 5), proving that the crystallites structure of $\mathrm{SiO}_{2}-\mathrm{ZnO}-\mathrm{Na}_{2} \mathrm{O}-\mathrm{Y}_{2} \mathrm{O}_{3}$ glass was more complex and the addition of $\mathrm{Y}_{2} \mathrm{O}_{3}$ promotes the crystallization of the galss.

Figure 6 shows the cross-section SEM images of the glass/ceramic composites. Obviously, a well bonded and

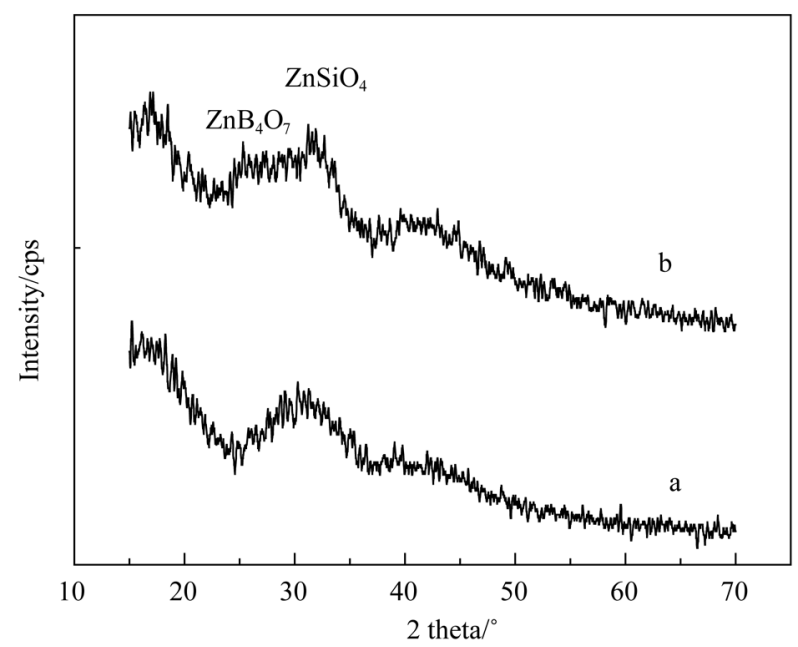

Figure 3. Surface $\mathrm{XRD}$ patterns of the as-prepared glasses (a. $\mathrm{SiO}_{2}-\mathrm{ZnO}-\mathrm{Na}_{2} \mathrm{O}$; b. $\mathrm{SiO}_{2}-\mathrm{ZnO}-\mathrm{Na}_{2} \mathrm{O}-\mathrm{Y}_{2} \mathrm{O}_{3}$ ).

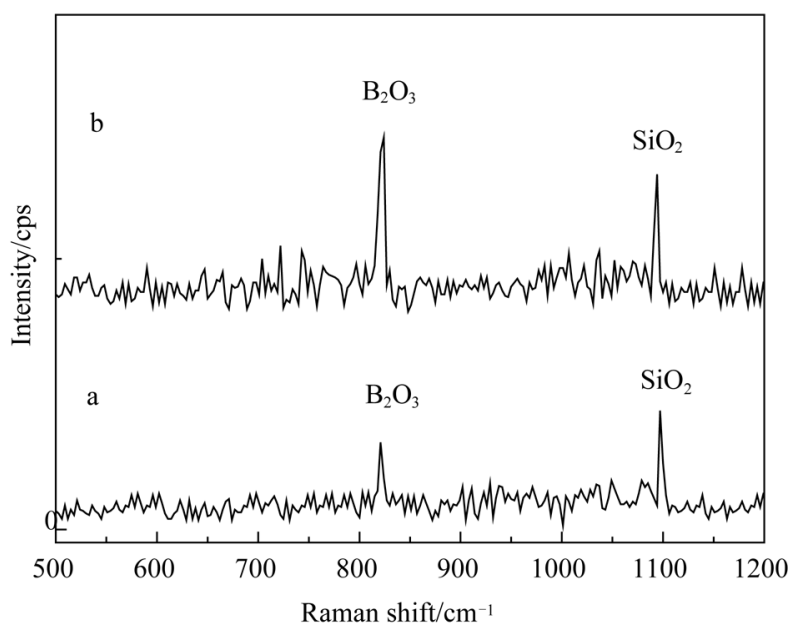

Figure 4. Raman patterns of the as-prepared $\mathrm{SiO}_{2}-\mathrm{ZnO}$ $\mathrm{Na}_{2} \mathrm{O}$ glasses $\left(\right.$ a. $^{1200}{ }^{\circ} \mathrm{C}$; b. $\left.1100^{\circ} \mathrm{C}\right)$.

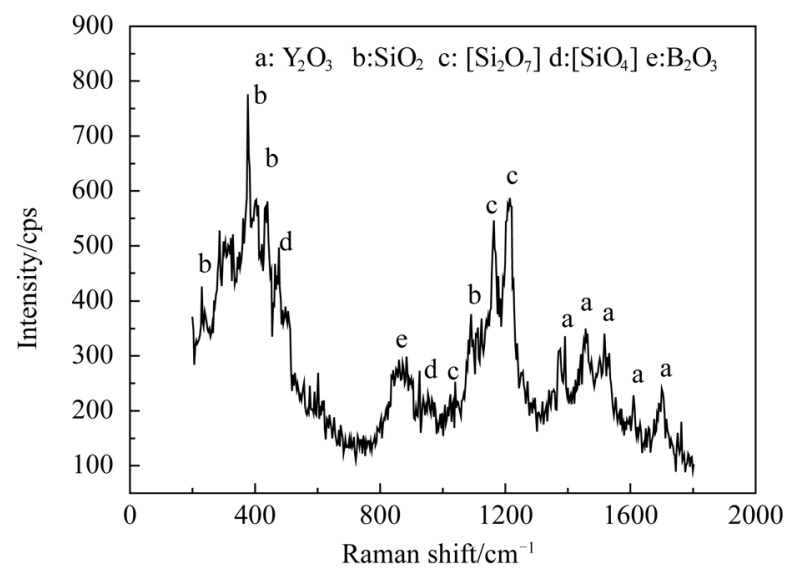

Figure 5. Raman pattern of the as-prepared $\mathrm{SiO}_{2}-\mathrm{ZnO}$ $\mathrm{Na}_{2} \mathrm{O}-\mathrm{Y}_{2} \mathrm{O}_{3}$ glasses.

condensed glass layer on the surface of ceramic substrate without holes and cracks was achieved, which indicated the good match of the physical and chemical compatibility between the glass layer and ceramic base and that the use of the glass and adoption of processing were reasonable.

The thermal expansion coefficients of the ceramic substrate and the glasses are displayed in Table 2. Thermal expansion coefficient of both $\mathrm{SiO}_{2}-\mathrm{ZnO}-\mathrm{Na}_{2} \mathrm{O}$ glass and $\mathrm{SiO}_{2}-\mathrm{ZnO}-\mathrm{Na}_{2} \mathrm{O}-\mathrm{Y}_{2} \mathrm{O}_{3}$ glass were less than that of ceramic tile. Comparatively, the thermal expansion coefficient of $\mathrm{SiO}_{2}-\mathrm{ZnO}-\mathrm{Na}_{2} \mathrm{O}$ glass was closer to that ceramic tile which is crucial to promote the strength of the composites. During the course of cooling down, compressive stress can be formed in glass layer and the wider the difference in thermal expansion coefficient between the glass and the ceramic tile is, the higher the compressive stress is; too much compressive stress can lead to 


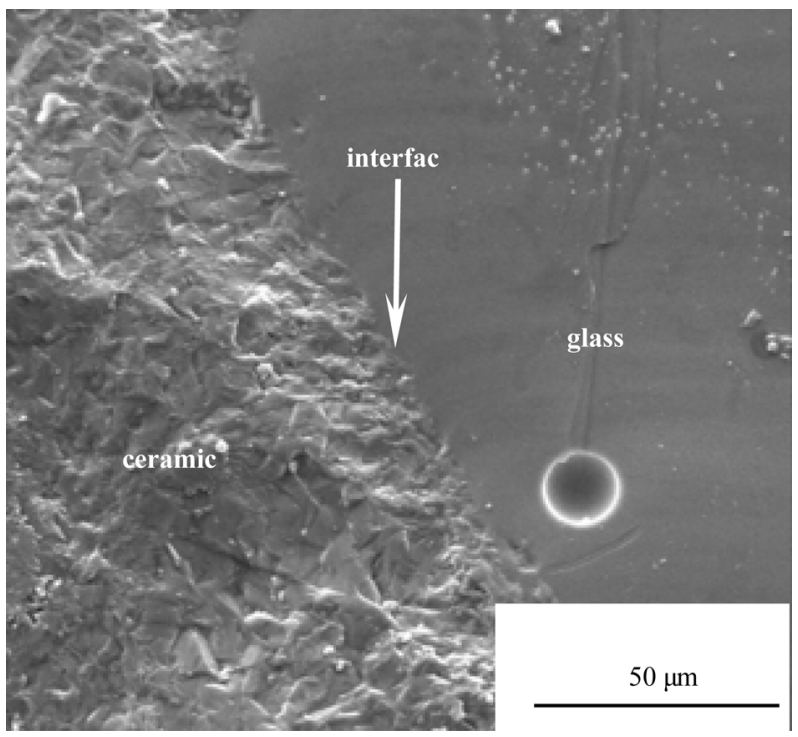

(a)

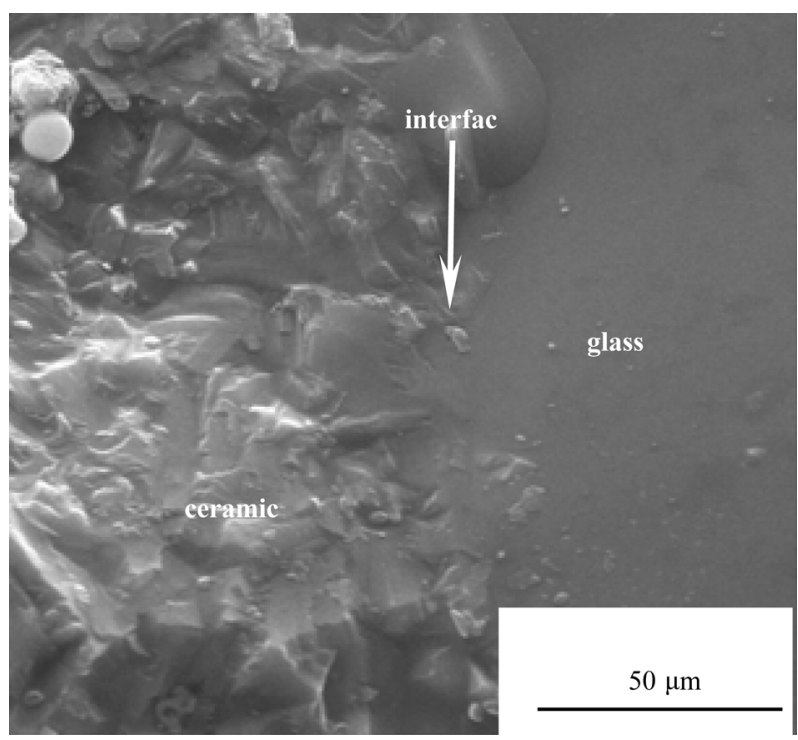

(b)

Figure 6. The cross-section SEM images of the glass/ceramic composites (a. $\mathrm{SiO}_{2}-\mathrm{ZnO}-\mathrm{Na}_{2} \mathrm{O} / \mathrm{ceramics}$ b. $\mathrm{SiO} \mathrm{O}_{2}-\mathrm{ZnO}-\mathrm{Na}_{2} \mathrm{O}-$ $\mathbf{Y}_{2} \mathbf{O}_{3}$ /ceramics).

Table 2. Thermal expansion coefficient of the ceramics substrate and the glasses $\left(\times 10^{-6} / \mathrm{K}\right)$.

\begin{tabular}{ccccc}
\hline Temperature & $40^{\circ} \mathrm{C}-400^{\circ} \mathrm{C}$ & $40^{\circ} \mathrm{C}-500^{\circ} \mathrm{C}$ & $40^{\circ} \mathrm{C}-600^{\circ} \mathrm{C}$ & $40^{\circ} \mathrm{C}-700^{\circ} \mathrm{C}$ \\
\hline $\mathrm{SiO}_{2}-\mathrm{ZnO}-\mathrm{Na}_{2} \mathrm{O}-\mathrm{Y}_{2} \mathrm{O}_{3}$ & 5.9885 & 5.9959 & 6.1207 & 6.5781 \\
$\mathrm{SiO}_{2}-\mathrm{ZnO}-\mathrm{Na}_{2} \mathrm{O}$ & 6.2133 & 6.3438 & 6.8154 & 7.1873 \\
Ceramic tile & 6.7091 & 6.9815 & 7.6889 & 7.3512 \\
\hline
\end{tabular}

cracks of the glass layer and deformation of the composites. Thus, it is necessary to control the difference in the thermal expansion coefficients.

Figure 7 shows the relationship between the bending strength of glass/ceramics composites and the sintering temperature. The bending strength of the composites increases with the sintering temperature, and when the temperature was about $1180^{\circ} \mathrm{C}$, the bending strength of the mullite ceramic tile reached the highest value of 95.9 $\mathrm{MPa}$. After covering with the $\mathrm{SiO}_{2}-\mathrm{ZnO}-\mathrm{Na}_{2} \mathrm{O}$ glass, the bending strength was greatly improved to about 101.3 MPa and 5.2\% enhanced. By comparison, when the $\mathrm{SiO}_{2}-\mathrm{ZnO}-\mathrm{Na}_{2} \mathrm{O}-\mathrm{Y}_{2} \mathrm{O}_{3}$ glass is coated on the surface of the ceramic tile and sintered at the temperature of $1100^{\circ} \mathrm{C}$, the bending strength peaked at $106.3 \mathrm{MPa}$ and $10.7 \%$ enhanced. This was not only caused by massive microcrystals of the glass layer, but also the lower compressive stress formed in the glass layer. In addition, the crystal structure of $\mathrm{SiO}_{2}-\mathrm{ZnO}-\mathrm{Na}_{2} \mathrm{O}-\mathrm{Y}_{2} \mathrm{O}_{3}$ glass was more complicated and its high crystallization temperature was helpful to improve the density of the composites during the course of sintering, which reduced the sintering temperature and sharply improved the strength of the com- posites.

\section{Conclusions}

$\mathrm{SiO}_{2}-\mathrm{ZnO}-\mathrm{Na}_{2} \mathrm{O}$ glass and $\mathrm{SiO}_{2}-\mathrm{ZnO}-\mathrm{Na}_{2} \mathrm{O}-\mathrm{Y}_{2} \mathrm{O}_{3}$ glass on the surface of large-size ultra-thin mullite ceramic tile was successfully prepared by a distributing sintering

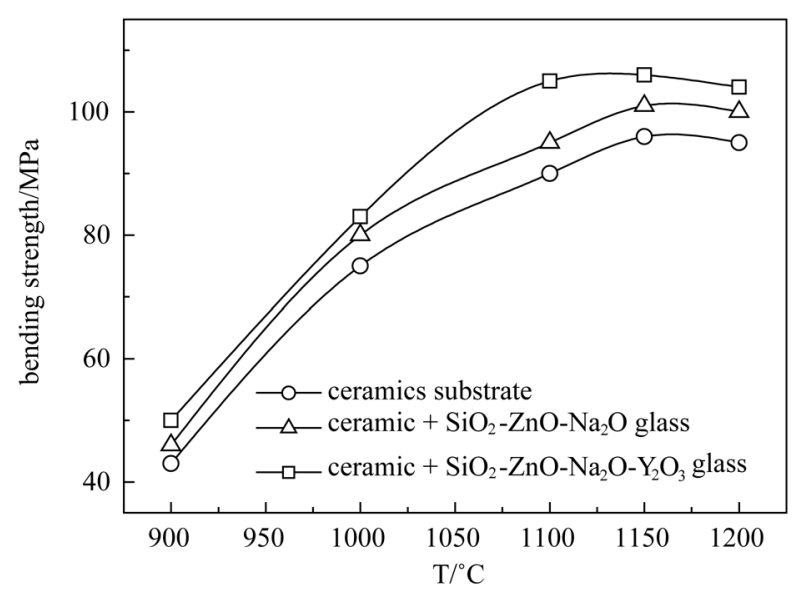

Figure 7. Relationship between the bending strength of glass/ceramics composites and the sintering temperature. 
method. The crystallization temperature of $\mathrm{SiO}_{2}-\mathrm{ZnO}$ $\mathrm{Na}_{2} \mathrm{O}-\mathrm{Y}_{2} \mathrm{O}_{3}$ glass was higher according to DTA analysis, and the XRD and Raman analysis indicateed that the crystallite structure of $\mathrm{SiO}_{2}-\mathrm{ZnO}-\mathrm{Na}_{2} \mathrm{O}-\mathrm{Y}_{2} \mathrm{O}_{3}$ glass was more complicated with $\mathrm{ZnB}_{4} \mathrm{O}_{7}, \mathrm{ZnSiO}_{4}, \mathrm{~B}_{2} \mathrm{O}_{3}, \mathrm{Y}_{2} \mathrm{O}_{3}$ and $\mathrm{SiO}_{2}$ crystal structures in the glass. The thermal expansion coefficients of the $\mathrm{SiO}_{2}-\mathrm{ZnO}-\mathrm{Na}_{2} \mathrm{O}-\mathrm{Y}_{2} \mathrm{O}_{3}$ glass were lower than the mullite ceramics tile, and the bending strength of the composites after sintering at $1150^{\circ} \mathrm{C}$ was obviously improved and reached 106.2 MPa and 10.7\% enhanced when compared with the mullite ceramic substrate.

\section{Acknowledgements}

This work has been supported by the Graduate Innovation Foundation of SUST.

\section{REFERENCES}

[1] Z. Q. Sheng, "Preparation of High-Strength Super-Thin Architectural Ceramic Tile Used on the Exterior Wall," Foshan Ceramics, Vol. 13, No. 6, 2003, pp. 17-19.
[2] J. E. Zhou, Y. Q. Ma and J. Wang, "Study on Improving the Fired Body's Properties of Super-Thin Architectural Ceramic Tile," Journal of Ceramics, Vol. 27, No. 3, 2006, pp. 243-249.

[3] D. Chen and N. C. Chen, "Research Development of Mullite,” Mineral Resources and Geology, Vol. 18, No. 2, 2004, pp. 18-22.

[4] Y. J. Liu, X. F. Xiu and L. Y. Cao, "Research on High Strength Mullite Based Microcrystalline Ceramics Thin Tiles,” Journal of Synthetic Crystals, Vol. 39, 2009, pp. 156-159.

[5] M. S. Ma, W. Ni and Y. L. Wang, "The Effect of $\mathrm{TiO}_{2}$ on Phase Separation and Crystallization of Glass-Ceramics in $\mathrm{CaO}-\mathrm{MgO}-\mathrm{Al}_{2} \mathrm{O}_{3}-\mathrm{SiO}_{2}-\mathrm{Na}_{2} \mathrm{O}$ System," Journal of NonCrystalline Solidsy, Vol. 354, No. 52-54, 2008, pp. 53955401.

[6] J. H. Kim, S. J. Hwang and W. Y. Sung, "Effect of Anorthite and Diopside on Dielectric Properties of $\mathrm{Al}_{2} \mathrm{O}_{3}$ /Glass Composites Based on High Strength of LTCC Substrate," Journal of Materials Science, Vol. 43, No. 12, 2008, pp. 4009-4015. doi:10.1007/s10853-007-2231-4 